\title{
Relative growth and sexual maturity of the freshwater shrimp Palaemon pandaliformis (Crustacea, Palaemonidae) in northeastern of Brazil (Canavieiras, Bahia)
}

\author{
Lucas R. P. Paschoal ${ }^{1,2}$, Fernanda J. Guimarães ${ }^{1}$ \& Erminda C. G. Couto ${ }^{1}$
}

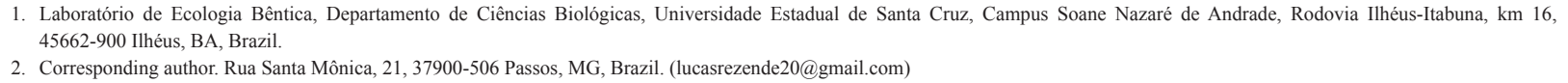

\begin{abstract}
This study comprises the description of relative growth and sexual maturity of a population of Palaemon pandaliformis Stimpson, 1871 in Salsa River (Northeastern Brazil). Samples were collected monthly between September 2009 and August 2010. Females were larger, heavier, and showed a greater allometric coefficient $(b)$ than male specimens. Only carapace length vs. pleura length in females presented a significant difference in the relative growth pattern, indicating a puberty moult. This relationship is strictly correlated to reproduction and its success rate in female shrimps. Estimated carapace length in $50 \%$ of mature females (CL ) was $4.53 \mathrm{~mm}$. It was not possible to compare obtained $\mathrm{CL}$ results due to a lack of studies on this species. Comparison was based on the size of the smallest captured ovigerous female (3.81 CL $\mathrm{mm}^{5}$ ), which is within the scope of recorded size for estuaries located in higher latitudes. This study reveals the lack of research on this genre in freshwater environments on a national and global scale.
\end{abstract}

KEYWORDS. Caridea, allometric growth, morphometric relationships.

RESUMO. Crescimento relativo e maturidade sexual de Palaemon pandaliformis (Crustacea, Palaemonidae) no Nordeste do Brasil (Canavieiras, Bahia). Foram descritos o crescimento relativo e a maturidade sexual de uma população de Palaemon pandaliformis Stimpson, 1871 do rio Salsa (Nordeste do Brasil). As coletas foram realizadas mensalmente entre setembro de 2009 e agosto de 2010. As fêmeas foram maiores, mais pesadas e exibiram um coeficiente alométrico $(b)$ maior que os machos. Apenas a relação comprimento de carapaça vs. comprimento de pleura nas fêmeas, apresentou uma diferença significativa no padrão de crescimento relativo, evidenciando a muda da puberdade. Esta relação é estritamente correlacionada aos eventos reprodutivos e ao sucesso deste em fêmeas de carídeos. O comprimento da carapaça em que $50 \%$ das fêmeas estão maduras (CL ) foi estimado em $4,53 \mathrm{~mm}$. Não foi possível comparar os resultados de CL obtidos devido à falta de estudos enfocando a espécie. A comparấção foi feita através do tamanho da menor fêmea ovígera capturada (3,81 CL mím), o qual está dentro da amplitude de tamanho registrada para estuários localizados em latitudes mais elevadas. Este trabalho aponta a falta de estudos para este gênero em ambientes dulceaquícolas, uma vez que estes são raros, mesmo em escala nacional e global.

PALAVRAS-CHAVE. Caridea, crescimento alométrico, relações morfométricas.

The growth of crustaceans is discontinuous and limited by the presence of a rigid, chitinous, calcified exoskeleton (KING, 1995). Careful measuring allows the conducting of morphometric studies that can clarify certain biological aspects within the population related to growth variability of a specific part of the body or structure (HARTNOLL, 1978).

The relationship between the size of certain structures and body lengths is called relative or allometric growth (TeISSIER, 1960). The presence of growth centres is any given area causes significant differences in the allometric coefficient (SHAW, 1928). The allometric equation $Y=a \cdot X^{b}$ (HuXLEY, 1950) is applied to describe the relative growth pattern of animals, being that $b$ is the allometric constant that expresses the relation between two body sizes. If $b$ is equal to 1 (or 3 , in the case of a three dimensional variable such as weight), growth is isometric, which means that both dimensions grow proportionally. When $b$ is greater than 1 , growth is allometrically positive and the analysed structure (Y) grows at a higher scale than body length (X). If $b$ is less than 1, allometry is negative and $\mathrm{Y}$ grows at a lesser scale in comparison with $\mathrm{X}$. These relations allow the interconversion of data of a specific body size to another (HARTNOLL, 1982).
Comparison of allometric coefficient $(b)$ between sexes and between juvenile and adult samples is widely adopted to visualize sexual dimorphism and estimate sizes of morphological sexual maturity (HARTNOLL, 1974). Differences in allometric coefficients between sexes have been studied in Palaemonidae [Botello \& Alvarez (2006) for Creaseria morleyi (Creaser, 1936); CartaXana (2003) for Palaemon longirostris H. Milne Edwards, 1837 and BILGIN et al. (2009a,b), for $P$. elegans Rathke, 1837 and $P$. adspersus Rathke, 1837]. These studies show alterations in relative growth rates of secondary sexual characters (e.g. presence of appendix masculina, organization of the brood pouch) when the animal is subject to the puberty moult, and these alterations are related to sexual maturity (Mossolin \& BUENO, 2003; BÉGUER et al., 2010).

In spite of efforts to study relative growth in decapods (see HARTNOLL, 2001; for revision), of the economic importance of some species of the infraorder Caridea (Almeida et al., 2010) and of the large number of Palaemonidae described for Brazil (60 species) (FERREIRA et al., 2010), there is a significant shortage of studies related to dimorphism and sexual maturity for species of the genus Palaemon Weber, 1795.

Only two articles about relative growth were 
published on this genus in Brazil: ANGer \& MorerRA (1998) that determine the allometric relationships for Palaemon pandaliformis Stimpson, 1871 and $P$. northropi Rankin, 1898 in São Sebastião and Ilha Bela - north coast of São Paulo, while Pralon \& NegreirosFransozo (2006), analysed dimorphism and sexual maturity based on allometric relationships for $P$. northropi in Ubatuba (north coast of São Paulo).

The aim of this study is to verify variability of relative growth of the $P$. pandaliformis population and estimate the size of sexual maturity based on the female morphometric data, along a stretch of Salsa River, Canavieiras, state of Bahia, Brazil

\section{MATERIAL AND METHODS}

The Salsa River ( $15^{\circ} 42^{\prime} \mathrm{S}$; $\left.38^{\circ} 59^{\prime} \mathrm{W}\right)$ is located in the south of the state of Bahia, northeastern of Brazil. It is considered one of the main tributaries of River Pardo, with a basin that covers an area of $30,360 \mathrm{~km}^{2}$ (RochA FiLHo, 1976). This region is subject to in natura domestic sewage discharge, exploitation of artisanal and commercial fishing of fish and shrimp, nature tourism and water sports (Lucas R. P. Paschoal, pers. obs.).

Samples were collected during the day on a monthly basis between September 2009 and August 2010, along a stretch of Salsa River. Shrimp were captured using a hand net $(0.5 \mathrm{~mm}$ mesh) pulled through marginal vegetation and macrophyte banks for 15 minutes.

After collection, the samples were conserved in $70 \%$ alcohol and transported to the Laboratório de Oceanografia Biológica of the Universidade Estadual de Santa Cruz. Samples were identified according to Melo (2003). Sex of the individuals was determined by an examination of the shape of endopodite of the first pair of pleopods; in mature shrimps, the sex was confirmed by the presence or absence of the masculine sexual appendix in the endopodite of the second pair of pleopods (BAUER, 2004).
This procedure allowed identification of the minimum body size at which individuals could be sexed. Because smaller individuals were morphologically similar to young females, all individuals with carapace length less than the smaller identified male were counted as not sexable (NS). These individuals were taken off to the analysis, avoiding a statistical error into our morphometric data for both sexes.

The shrimps were measured using a stereomicroscope coupled to an imagery system. Images were analysed with ImageJ software version 1.45 (RASBAND, 2006). Adopted scaling was proposed by ANGER \& MOREIRA (1998): carapace length (CL), total length (TL), abdomen length (AL), and pleura length (PL) (Fig. 1). Fresh weight (W) of each individual was recorded using a precision scale $(0.001 \mathrm{~g})$

Power functions were adjusted relating body size (dependent variables) with carapace length (CL) (independent variable). Equations were subsequently linearized $(\log y=\log a * \log x-b)$. Values of the allometric constant $(b)$ were tested using the $t$ test, as $\mathrm{H}_{0}: b=1$ (or 3 in the case of weight), and used to determine growth patterns of a specific body part in relation to carapace length. Differences between slopes and intercepts of straight lines between the sexes were compared using analysis of covariance - ANCOVA (ZAR, 1996).

The relationships were verified by a coefficient of determination $\left(\mathrm{r}^{2}\right)$, while Snedecor's F test $(a=0.01)$ (SOKAL \& ROHLF, 1995) was used to verify the presence of one or two regression lines. The empirical points were distinguished from immature and mature lines by the best fit of linear regression analysis, and ANCOVA was performed to compare the straight lines of each growth phase.

The size in which $50 \%$ of females reach morphological sexual maturity was determined based on the proportion of mature females (determined by relative growth) in each size class, adjusted by the logistic equation provided by CAMPBELL (1983) and KING (1995): $P=1 /(1+\exp [-(a+b \mathrm{CL})])$, where $a$

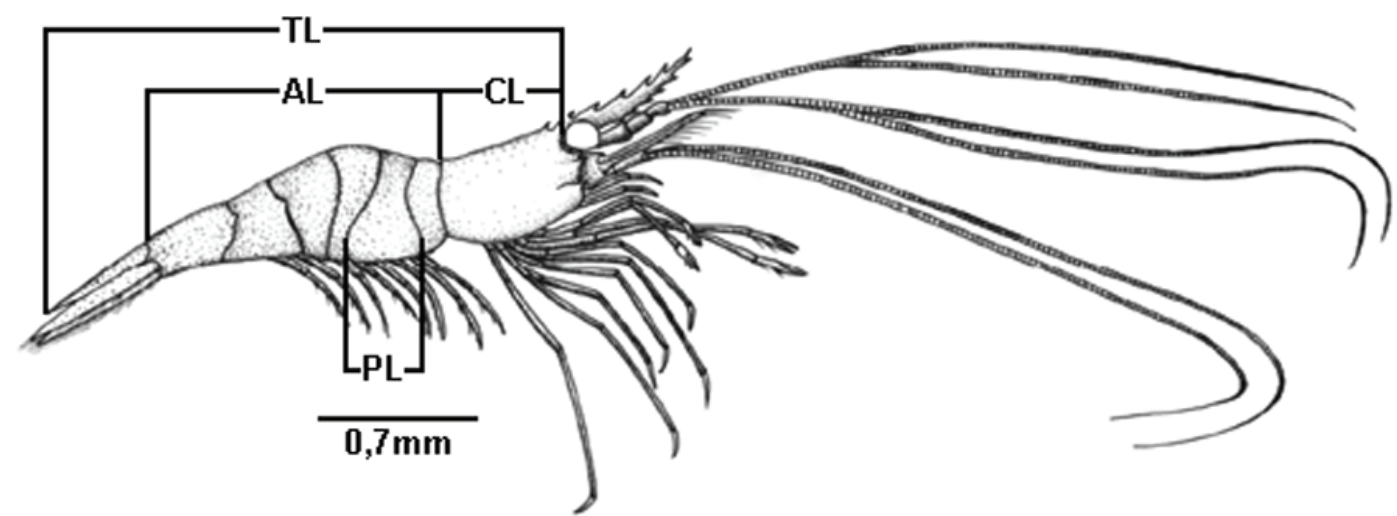

Fig. 1. General scheme for shrimp size dimensions (TL, total length; AL, abdomen length; CL, carapace length; PL, pleura length). Modified from R. C. Mortari (unpubl. data). 
and $b$ are the estimated coefficients. The equation was adjusted using the least squares method.

$C L_{50}$ (carapace length in which $50 \%$ of females reach morphological sexual maturity) was estimated from the proportion of the constants $a$ and $b\left(\mathrm{CC}_{50}=\right.$ $(a / b)) . T L_{50}$ was estimated using the equations TL $v s$. $\mathrm{CL}$, for subsequent comparison in other studies.

\section{RESULTS}

A total of 4,151 individuals were collected: 2,837 males, 1,256 females (452 ovigerous), and 58 not sexable. Total length varied from 8.12 to $31.70 \mathrm{~mm}$. Measurements of the smallest ovigerous female were $3.81 \mathrm{~mm} \mathrm{CL}$ and $14.78 \mathrm{~mm}$ TL. In general, females were larger (CL, TL), heavier and had larger abdomen and pleura than males $(p<0.001)$ (Tab. I).
The table II shows linear regressions of morphometric data and results of the comparison (ANCOVA) of straight lines of males and females. The lines differ in all sexes in all analysed relationships.

Only the PL vs. CL relationship for females showed a significant difference in the relative growth pattern between the juvenile and adult phases (Snedecor's F test: $a<0.01$ ). There was also overlapping of straight lines of the smallest captured mature female with a CL of $3.51 \mathrm{~mm}$ (i.e. $0.54 \mathrm{log}$ ) and the largest immature female with a $\mathrm{CL}$ of $6.16 \mathrm{~mm}$ (i.e. $0.79 \log$ ) (Fig. 2). $\mathrm{CL}_{50}$ of females was $4.53 \mathrm{~mm}$ while $\mathrm{TL}_{50}$ was $16.03 \mathrm{~mm}$ (Fig. 3).

The ANCOVA result shows that regression slopes of immature and mature females do not differ significantly, although significant differences were recorded for the intercepts values (Tab. III).

Tab. I. Palaemon pandaliformis Stimpson, 1871: mean, minimum and maximum values of the analyzed variables of males, females and not sexable (NS) individuals of a population from Canavieiras, state of Bahia, Brazil (X, mean values; sd, standard deviation; CL, carapace length; TL, total length; AL, abdomen length; PL, pleura length; W, body wet weight; $T$, Test $\mathrm{t}$ between sexes, NS excluded; ***, statistically significant at $p<0.001$.)

\begin{tabular}{|c|c|c|c|c|c|}
\hline Variables & Group & $\mathrm{X} \pm \mathrm{sd}$ & Minimum & Maximum & $T$ \\
\hline \multirow{3}{*}{$\mathrm{CL}(\mathrm{mm})$} & NS & $2.77 \pm 0.61$ & 1.22 & 3.39 & \multirow{3}{*}{$-22.60^{* * * *}$} \\
\hline & $\hat{\jmath}$ & $5.55 \pm 0.88$ & 3.40 & 8.00 & \\
\hline & q & $6.41 \pm 1.39$ & 3.43 & 10.20 & \\
\hline \multirow{3}{*}{$\mathrm{TL}(\mathrm{mm})$} & NS & $12.11 \pm 0.60$ & 6.30 & 21.85 & \multirow{3}{*}{$-13.54^{* * * *}$} \\
\hline & $\hat{\sigma}$ & $19.91 \pm 3.30$ & 11.20 & 28.30 & \\
\hline & $q$ & $21.71 \pm 4.63$ & 8.12 & 31.70 & \\
\hline \multirow{3}{*}{$\mathrm{AL}(\mathrm{mm})$} & NS & $9.33 \pm 3.18$ & 3.64 & 18.76 & \multirow{3}{*}{$-8.43^{* * *}$} \\
\hline & $\hat{\sigma}$ & $14.37 \pm 2.80$ & 7.20 & 21.90 & \\
\hline & q & $15.30 \pm 3.81$ & 4.50 & 23.00 & \\
\hline \multirow{3}{*}{$\mathrm{PL}(\mathrm{mm})$} & NS & $1.70 \pm 0.60$ & 0.70 & 3.60 & \multirow{4}{*}{$-20.01^{* * * *}$} \\
\hline & $\widehat{\partial}$ & $3.57 \pm 0.41$ & 1.40 & 3.80 & \\
\hline & q & $3.60 \pm 1.00$ & 1.00 & 6.10 & \\
\hline \multirow{3}{*}{ W (g) } & NS & $33.69 \pm 29.89$ & 1.00 & 180.00 & \\
\hline & $\delta$ & $107.8 \pm 46.62$ & 2.00 & 354.00 & \multirow{2}{*}{$-18.05^{* * *}$} \\
\hline & q & $164.0 \pm 87.73$ & 2.00 & 352.00 & \\
\hline
\end{tabular}
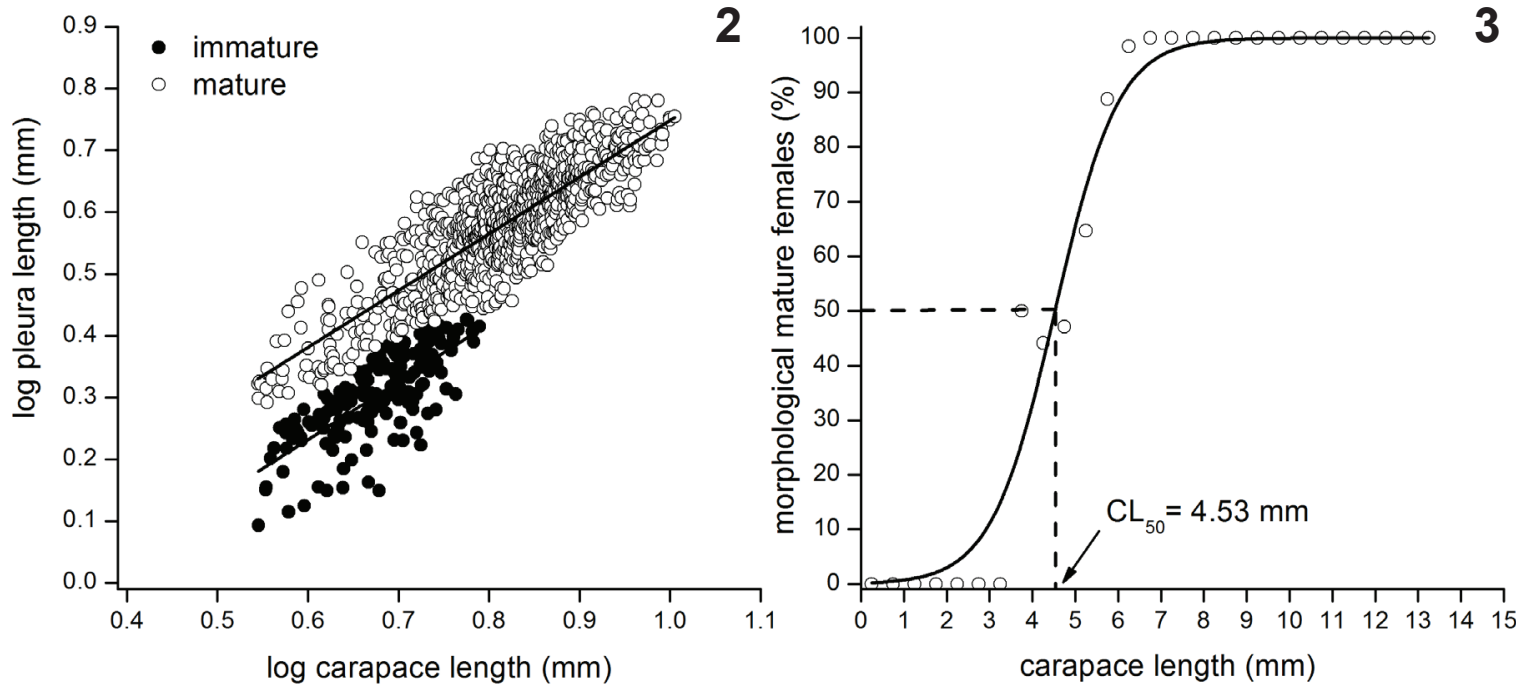

Figs 2, 3. Palaemon pandaliformis Stimpson, 1871 of a population from Canasvieiras, state of Bahia, Brazil: 2, relationship between pleura length $(P L)$ and carapace length (CL) of immature $(n=165)$ and mature $(n=1019)$ females with log transformed data (see Tab. III for regression equations); 3 , logistic function fitting the proportion of mature females to carapace length. $\mathrm{CL}_{50}$ corresponds to a proportion of $50 \%$ of mature females. 
Tab. II. Palaemon pandaliformis Stimpson, 1871 of a population from Canavieiras, state of Bahia, Brazil: linear regression of morphometric log transformed data and analysis of covariance (ANCOVA) between sex regressions lines ( $\mathrm{r} 2$, determination coefficient; A, allometry; *, statistically significant at $p<0.05 ; \bullet, \mathrm{b} \neq 3)$. Other abbreviations see Table I.

\begin{tabular}{|c|c|c|c|c|c|c|c|}
\hline \multirow{2}{*}{ Sex } & \multirow{2}{*}{ Linear regression } & \multirow{2}{*}{$\mathrm{N}$} & \multirow{2}{*}{$r^{2}$} & \multirow{2}{*}{$\mathrm{b} \neq 1$} & \multirow{2}{*}{ A } & \multicolumn{2}{|c|}{$F$-value } \\
\hline & & & & & & Y- intercept & Slope \\
\hline$\hat{\sigma}$ & $\mathrm{TL}=0.66 \mathrm{CL}+0.80$ & 2,724 & 0.39 & $-20.71 *$ & - & \multirow{2}{*}{$6.62^{*}$} & \multirow{2}{*}{$33.37^{*}$} \\
\hline$q$ & $\mathrm{TL}=0.80 \mathrm{CL}+0.68$ & 1,218 & 0.59 & $-10.11 *$ & - & & \\
\hline$\hat{\sigma}$ & $\mathrm{AL}=0.54 \mathrm{CL}+0.75$ & 2,701 & 0.18 & $-20.60^{*}$ & - & \multirow{2}{*}{$11.48^{*}$} & \multirow{2}{*}{$39.02^{*}$} \\
\hline q & $\mathrm{AL}=0.75 \mathrm{CL}+0.57$ & 1,194 & 0.39 & $-8.90 *$ & - & & \\
\hline 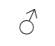 & $\mathrm{PL}=0.73 \mathrm{CL}-0.12$ & 1,487 & 0.40 & $-11.67 *$ & - & \multirow{2}{*}{$393.09^{*}$} & \multirow{2}{*}{255.60} \\
\hline q & $\mathrm{PL}=1.20 \mathrm{CL}-0.41$ & 1,181 & 0.76 & $10.10 *$ & + & & \\
\hline$\hat{\sigma}$ & $\mathrm{W}=1.70 \mathrm{CL}+0.73$ & 2.731 & 0.28 & $25.14 \bullet$ & - & \multirow{2}{*}{$13.75^{*}$} & \multirow{2}{*}{138.93} \\
\hline q & $\mathrm{W}=2.64 \mathrm{CL}-0.03$ & 1.179 & 0.60 & $5.706 \bullet$ & - & & \\
\hline
\end{tabular}

Tab. III. Palaemon pandaliformis Stimpson, 1871 of a population from Canavieiras, state of Bahia, Brazil: relationship between pleura (PL) and carapace length (CL) with log transformed data. Analysis of covariance between immature (n: 165) and mature (n: 1019) females (r , determination coefficient; A, allometry; *, statistically significant at $p<0.05$; ns: not significant).

\begin{tabular}{|c|c|c|c|c|c|c|}
\hline & \multirow{2}{*}{ Linear regression } & \multirow{2}{*}{$r^{2}$} & \multirow{2}{*}{$\mathrm{b} \neq 1$} & \multirow{2}{*}{ A } & \multicolumn{2}{|c|}{$F$-value } \\
\hline & & & & & Y- intercept & Slope \\
\hline Immature & $\mathrm{PL}=0.94 \mathrm{CL}+0.33$ & 0.56 & $-0.95^{n s}$ & 0 & \multirow{2}{*}{$928.58 *$} & \multirow{2}{*}{0.0638} \\
\hline Mature & $\mathrm{PL}=0.91 \mathrm{CL}+0.17$ & 0.71 & $-4.34 *$ & - & & \\
\hline
\end{tabular}

\section{DISCUSSION}

Females collected in river Salsa were larger and heavier, with larger abdomen and pleura than males sampled, which contrasts with the findings of authors such as Boschi (1974), who stated that males of the species of the Palaemonidae are generally the largest individuals of the population with a highly evident sexual dimorphism. This is frequently observed in species of the Macrobrachium Bate, 1868, mainly associated to size and form of the chelipeds of adult males (BoscHI, 1974), which also occurs with some species of Palaemon (BerGlund, 1981; KIM, 2005) such as P. longirostris, in that males had positive allometric growth (CARTAXANA, 2003).

In this study, the constant $b$ calculated in the TL vs. CL relationship for males was lower than that of females, indicating that carapace growth in relation to total length occurs at a lesser proportion. In individuals with the same $\mathrm{TL}$, carapace of females tends to be greater than that of males, as previously noted for other Palaemonidae Palaemon northropi, P. pandaliformis, Macrobrachium acanthurus (WIEGMANN, 1836) and M. olfersi (ANGER \& Moreira, 1998). BAUER (2004) suggests that as males of many species of this family do not protect or defend the reproductive females or their territory, a larger size would not be necessary. Energy can therefore be used to produce a large amount of sperm. Rafael C. Mortari (unpubl. data) reported individuals of $P$. pandaliformis of reduced size (1.5 mm CL) with developed secondary sexual characters and large amounts of sperm.

Pleura size of the second abdominal somite is directly related to the reproductive process of females. The $P L$ vs. $C L$ ratio differs between the sexes. This dimorphism can be related to the different functions of the pleura in each sex (HARTNOLL, 1974). Positive allometry for females is probably related to the fact that females incubate the eggs until they hatch. Larger brood pouch increase protection during egg deposition and incubation, optimizing the reproductive process (NAZARI et al., 2003; BAUER, 2004).

It was not possible to detect differences in the relative growth patterns between juvenile and adult males for all analysed ratios. In the case of females, only the PL vs. CL relationship differed between juvenile and adult specimens. Petriella \& Boschi (1997) stated that growth of crustaceans is relative, allometric and heterogonic. It is discontinuous, with gradual increasing of volume, size and weight in successive moults or abruptly in a single moult, such as the puberty moult. This separates the last juvenile stage from the first sexually mature stage, reflecting changes in relative growth of the animal (HARTNOLL, 1985). BAUER (2004) stated that the abdomen and the first three female abdominal segments undergo several morphological alterations to enhance egg protection. These alterations occur during the moult that precedes the first spawning, making the female sexually mature.

Puberty moults in Palaemonidae were occasionally studied; however, they were observed in the cephalothorax of Macrobrachium borellii (Nobili, 1896) (Collins \& Petriella, 1999), in the second pereopod of C. morleyi (Botello \& Alvarez, 2006) and the abdominal pleura of $P$. northropi (PrALON \& NeGreiros-Fransozo, 2006).

In this study, estimated $\mathrm{CL}_{50}$ was $4.53 \mathrm{~mm}$. However, there are no data of $\mathrm{CL}_{50}$ available for this species in other locations, which hinders comparisons. Studies conducted in the states of Rio de Janeiro and São Paulo presented records of the smallest ovigerous female. Wenner et al. (1985) and BAuer \& AbDAlla (2000) considered the presence and/or extrusion of eggs in female pleopods as indicators of sexual maturity, which is determined by length of the smallest 
captured ovigerous female. In this study, conducted in Salsa River (Canavieiras, BA), we recorded a CL of $3.81 \mathrm{~mm}$. In the estuary of Sahy River (Mangaratiba, RJ), Lima \& OshiRo (2002) recorded $5.20 \mathrm{~mm}$ for the smallest ovigerous female, while MorTARI et al. (2009) recorded 3.00 and $4.10 \mathrm{~mm}$ in the estuaries of Ubatumirim River and Comprido River (Ubatuba, SP), respectively. Consequently, data obtained for a freshwater environment (this study) were within the size scope recorded for estuarine environments located at higher latitudes. WenNER et al. (1985) and $\mathrm{OH}$ et al. (1999) stated that variations in maturity sizes are common in crustaceans, caused by variations in growth rate and several degrees of variability that may occur on a seasonal basis in a single habitat or in different locations.

A low number of ovigerous females under the $\mathrm{CL}_{50}$ measure were found in this study, only tree. These results suggest that there was synchrony between physiological and morphological maturity. Thus, the use of both techniques were appropriate to estimate size at maturity for Palaemon pandaliformis. Studies on this genus in freshwater environments are rare, even on a global scale. A revision of literature only produced KIM et al. (2008) with Palaemon paucidens De Haan, 1844 [in De Haan, 1833-1850] conducted in Lake Sukdang, South Korea, indicating the need for a greater number of studies with this genus.

Acknowledgements. We are sincerely thankful to Dr. Sergio João de Luca, who gave the opportunity to allow this work was supported by the project of CNPq (process \# 180342/2009-6) and financing the vehicles and boats that were used, helping in the logistical support in which the work can be performed successfully. This paper is part of M. Sc. degree dissertation on Zoology improved by the first author, who thanks the scholarship provided by Coordenadoria de Aperfeiçoamento de Pessoal de Nível Superior (CAPES)

\section{REFERENCES}

Almeida, A. O.; Mossolin, E. C. \& LuZ, J. R. 2010. Reproductive Biology of the Freshwater Shrimp Atya scabra (Leach, 1815) (Crustacea: Atyidae) in Ilhéus, Bahia, Brazil. Zoological Studies 49(2):243-252.

Anger, K. \& Moreira, G. S. 1998. Morphometric and reproductive traits of tropical caridean shrimps. Journal of Crustacean Biology 18:823-838.

BAUER, R. T. 2004. Remarkable shrimps. Adaptations and Natural History of the Carideans. Oklahoma, University Oklahoma Press. 316p.

Bauer, R. T. \& AbDalla, J. A. 2000. Patterns of brood production in the grass shrimp Palaemonetes pugio (Decapoda: Caridea). Invertebrate Reproduction and Development 38:107-113.

BÉGuer, M.; Bergé, J.; Girandin, M. \& Bö̈T, P. 2010. Reproductive biology of Palaemon longirostris (Decapoda: Palaemonidae) from Gironde estuary (France), with a comparison with other european populations. Journal of Crustacean Biology 30(2):175-185.

Berglund, A. 1981. Sex dimorphism and skewed sex ratios in the prawn species Palaemon adspersus and P. squilla. Oikos 36:158162.

Bilgin, S.; Ozen, O. \& SAmsun, O. 2009a. Sexual seasonal growth variation and reproduction biology of the rock pool prawn, Palaemon elegans (Decapoda: Palaemonidae) in the southern Black Sea. Scientia Marina 73(2):239-247. 2009b. Seasonal growth and reproduction biology of the Baltic prawn, Palaemon adspersus (Decapoda: Palaemonidae), in the southern Black Sea. Journal of the Marine Biological Association of the United Kingdom 89(3):509-519.

Boschi, E. E. 1974. Biologia de los crustaceos cultivables en America Latina. Carpas 6:1-24.

Botello, A. \& Alvarez, F. 2006. Allometric growth in Creaseria morleyi (Creaser, 1936) (Decapoda: Palaemonidae), from the Yucatan Peninsula, Mexico. Caribbean Journal of Science 42:171-179.

CAmpbell, A. 1983. Growth of tagged American lobsters, Homarus americanus, in the Bay of Fundy. Canadian Journal of Fisheries and Aquatic Sciences 40:1667-1675.

Cartaxana, A. 2003. Growth of the Prawn Palaemon longirostris (Decapoda, Palaemonidae) in Mira River and Estuary, SW Portugal. Journal of Crustacean Biology 23(2):251-257.

Collins, P. \& Petriella, A. 1999. Growth pattern of isolated prawns of Macrobrachium borellii (Crustacea, Decapoda, Palaemonidae). Invertebrates Reproduction Development 36(1):87-91.

Ferreira, R. S.; Vieira, R. R. R. \& D'Incao, F. 2010. The marine and estuarine shrimps of the Palaemoninae (Crustacea: Decapoda Caridea) from Brazil. Zootaxa 2606:1-24.

Hartnoll, R. G. 1974. Variation in growth pattern between some secondary sexual charaters in crabs (Decapoda, Brachyura). Crustaceana 27:131-136

1978. The determination of relative growth in Crustacea. Crustaceana 34:282-292.

1982. Growth. In: Abele, L. G. ed. Embryology, Morphology and Genetics. The Biology of Crustacea. New York, Academic Press, v. 2, p.111-196.

1985. Growth, sexual maturity and reproductive output. In Wenner, A. M. ed. Crustacean Issues. 3. Factors in Adult Growth. Rotterdam, A. A. Balkema, p.101-128.

2001. Growth in Crustacea - twenty years on. Hydrobiologia 449:111-122.

Huxley, J. S. 1950. Relative growth and form transformation. Proceedings of the Royal of London 137:465-469.

KIм, S. 2005. Population structure, growth, mortality, and size at sexual maturity of Palaemon gravieri (Decapoda: Caridea: Palaemonidae). Journal of Crustacean Biology 25:226-232.

KIM, J. C.; OH, C. W. \& PAIK, S. G. 2008. Reproduction and growth of the freshwater prawn, Palaemon paucidens (Decapoda: Palaemonidae) in a lake of Korea. Journal of Environmental Biology 29(2): 163-168.

KING, M. 1995. Fisheries biology, assessment and management Oxford, Blackwell. 341p.

Lima, G. V. \& Oshiro, L. M. Y. 2002. Aspectos reprodutivos de Palaemon pandaliformis (Stimpson) (Crustacea, Decapoda, Palaemonidae) no Rio Sahy, Mangaratiba, Rio de Janeiro, Brasil. Revista Brasileira de Zoologia 19(3):855-860.

Melo, G. A. S. 2003. Famílias Atyidae, Palaemonidae, Sergestidae. In: Melo, G. A. S. org. Manual de Identificação dos Crustacea Decapoda de água doce do Brasil. São Paulo, Loyola, p. 289415.

Mortari, R. C.; Pralon, B. G. N. \& Negreiros-Fransozo, M. L. 2009. Reproductive biology of Palaemon pandaliformis (Stimpson, 1871) (Crustacea, Decapoda, Caridea) from two estuaries in southeastern Brazil. Invertebrate Reproduction and Development 53(4):223-232.

Mossolin, E. C. \& Bueno, S. 2003. Relative Growth of the Second Pereiopod in Macrobrachium olfersi (Wiegmann, 1836) (Decapoda, Palaemonidae). Crustaceana 76:363-376.

Nazari, E. M.; Simões-Costa, M. S.; MÜller, Y. M. R.; Ammar, D \& Dias, M. 2003. Comparisons of fecundity, egg size and egg mass volume of the freshwater prawns Macrobrachium potiuna and Macrobrachium olfersi (Decapoda, Palaemonidae). Journal of Crustacean Biology 23:862-868.

Oh, C. W.; Hartnoll, R. G. \& Nash, R. D. M. 1999. Population dynamic of the common shrimp, Crangon crangon (L.), in Por Erin Bay, Isle of Man, Irish Sea. Journal of Marine Science 56:718-733.

Petriella, A. M. \& Boschi, E. E. 1997. Crecimiento en crustáceos decápodos: resultados de investigaciones realizadas en Argentina. Investigaciones Marinas Valparaíso 25:135-157. 
Pralon, B. G. N. \& Negreiros-Fransozo, M. L. 2006. Population biology of Palaemon (Palaeander) northropi Rankin, 1898 (Crustacea, Decapoda, Palaemonidae) in a tropical South American estuary. Acta Limnologica Brasiliensia 18(1):77-87.

Rasband, W. S. 2006. ImageJ: Image Processing and Analysis in Java. National Institutes of Health, Research Services Branch Bethesda. Available at: <http://rsb.info.nih.gov/ij/docs/index. html>. Accessed on: 01.08.2010.

Rocha Filho, C. A. 1976. Diagnóstico Sócio-Econômico da Região Cacaueira, vol. 5: Recursos Hídricos. Comissão Executiva do Plano da Lavoura Cacaueira e Instituto Interamericano de Ciências Agrícolas - OEA. Rio de Janeiro, Cartográfica Cruzeiro do Sul. 92p.
SHAw, M. E. 1928. A contribution to the study of relative growth of parts in Inachus dorsettensis. British Journal of Experimental Biology 6:145.

SoKal, R. R. \& Rohlf, F. J. 1995. Biometry: the principle and practice of statistics in biological research. New York, W. H. Freeman. 880p.

Teissier, G. 1960. Relative growth. In: Waterman, T. H. ed. The physiology of Crustacea: Metabolism and growth. New York, Academic Press, p. 537-560

Wenner, A. M.; Page, H. M. \& Siegel, P. R. 1985. Variation in size at onset of egg production. In: WENNER, A. M. ed. Factors in adult growth. Rotterdam, A. A. Balkema, p. 149-163.

ZAR, J. H. 1996. Biostatistical analysis. New Jersey, Prentice Hall. 662p. 